\title{
Vegetation on Gunnison's Prairie Dog Colonies in Southwestern Colorado
}

\author{
Madeline N. Grant-Hoffman ${ }^{1}$ and James K. Detling ${ }^{2}$ \\ Authors are ${ }^{1}$ Research Assistant, Department of Biology and Wildife, University of Alaska, Fairbanks, AK 99775; and \\ ${ }^{2}$ Professor, Department of Biology and Senior Research Scientist, Natural Resource Ecology Laboratory, \\ Colorado State University, Fort Collins, CO 80523.
}

\begin{abstract}
Prairie dogs (Cynomys spp.) have been labeled keystone species because of the role they play as disturbance creators and ecosystem engineers in the western grasslands of North America. Most studies have concentrated on the black-tailed species (C. ludovicianus); however, other species of prairie dogs may have different effects on their ecosystems. We measured plant cover and biomass, canopy height, and plant nitrogen concentration on and off 6 Gunnison's prairie dog (C. gunnisoni) towns and 6 paired areas off prairie dog towns in southern Colorado. Multivariate analysis of variance and analysis of variance showed no significant differences $(P>0.05)$ in vegetation cover or biomass on and off of Gunnison's prairie dog towns, contrary to what has been found for black-tailed prairie dog towns. No significant differences were found in canopy height $(P>0.05)$; however, this may be due to already short vegetation $(5-7 \mathrm{~cm})$. Only 1 of 4 focal plants showed a significant difference in nitrogen concentration. No significant differences were found in species diversity on and off prairie dog towns; however, because of drought, these results are inconclusive. This study found few vegetation differences on and off Gunnison's prairie dog towns. Furthermore, those differences were more subtle than those reported on black-tailed prairie dog towns. While the mechanisms for differences in vegetation on and off Gunnison's prairie dog towns may be similar to those on black-tailed prairie dog towns, the magnitude of these differences may be different.
\end{abstract}

\section{Resumen}

Los perritos de la pradra (Cynomys spp.) ha sido designado una especial de clave a causa del rollo que ellos juegan como creadoros de perturbaciones y ingenieros de ecosistemas en la pradera del oeste de Norte America. La mayoría de los estudios han concentrado en la especie de cola negra (C. ludovicianus); sin embargo, otras especias de perritos de la pradera puedan tener efectos diferentes sobre sus ecosistemas. Medimos la cubierta y biomasa de las plantas, la altura de dosel, y el concentración de nitrógeno de plantas encima de 6 pueblos del perritos de la pradera typo Gunnison y 6 áreas apareados fuera de los pueblos en el sur de Colorado. El análisis multivariate y el análisis de variación no mostró diferencias signifícativas $(P>0.05)$ en la cubeirta de vegetación ni biomasa entre de y fuera de pueblos de perritos de la pradera typo Gunnison, al contrario de lo que ha sido encontrado para pueblos de perritos de la pradera de cola negra. Ninguna differencia significativa se encontraron en la altura de dosel $(P>0.05)$; sin embargo, este puede estar debido a vegetación ya corta $(5-7 \mathrm{~cm})$. Sólo uno de cuatro plantas focales mostró una diferencia signigicativa en la concentración de nitrógeno. No se encontraron ninguna diferencia significativa en la diversidad de las especias entre de y fuera de los pueblos de los perritos de la pradera, pero por causa de la sequía estos resultados no esta decisisivos. Este estudio encontró pocas diferencias de vegetación entre de y fuera de los pueblos de los perritos de la pradera typo Gunnison. Además, las diferencias que nos encontramos son más sutil que las diferencias informado sobre los pueblos de los perritos de la pradera de cola negra. Mientras los mecanismos para los diferencias en la vegetación entre de y fuera de los pueblos de los perritos de la pradera typo Gunnison pueden ser semejantes a ésos para los pueblos de los perritos de la pradera de cola negra, la magnitude de estas diferencias puede ser diferente.

Key Words: Cynomys gunnisoni, Cynomys ludovicianus, shoot nitrogen, grazing

\section{INTRODUCTION}

Prairie dogs (Cynomys spp.) have been a focus of scientific research and political debate since Lewis and Clark first wrote

Research was funded by the Bureau of Land Management (BLM), Gunnison, Colorado, and the Peaks AGEP (Alliance for Graduate Education and the Professorate) fellowship.

At the time of the research, Grant-Hoffman was a teaching assistant in the Department of Biology, Colorado State University, Fort Collins, CO 80523.

Correspondence: M. N. Grant-Hoffman, Dept of Biology and Wildlife, University of Alaska, Fairbanks, AK 99775. Email: n.granthoffman@gmail.com

Manuscript received 21 July 2004; manuscript accepted 27 June 2005. of them in their journals. Many early researchers considered them pests that compete with livestock and advocated their eradication (Merriam 1902). Eradication programs, habitat loss and fragmentation, and the introduction of plague (Yersinia pestis) have led to the continuing decline of prairie dog populations (Cully and Williams 2001). Many studies have examined the effects of black-tailed prairie dogs (C. ludovicia$n u s$ ) on grassland vegetation, soil nutrient cycling (Coppock et al. 1983; Holland and Detling 1990; Winter et al. 2002), and other grassland animal species (Coppock et al. 1983; Kotliar et al. 1999). Grazing, burrowing and mound building, and the active removal of taller vegetation initiate these changes on black-tailed prairie dog towns, often creating conspicuous 
patches in the landscape (Coppock et al. 1983; Archer et al. 1987; Whicker and Detling 1988; Farrar 2002).

Plant species composition on black-tailed prairie dog towns generally shifts over time from grasses to forbs in northern mixed grass (Coppock et al. 1983; Archer et al. 1987; Whicker and Detling 1988) and shortgrass prairies (Winter et al. 2002). Grazing by black-tailed prairie dogs also leads to increases in bare ground (Coppock et al. 1983) and lower canopy height (Archer et al. 1987; Winter et al. 2002; Guenther and Detling 2003). These alterations and their subsequent influences on associated species have led to prairie dogs being characterized as a keystone species in many grasslands of western North America (Miller et al. 1994; Kotliar et al. 1999). However, these characterizations have been based largely on studies of black-tailed prairie dogs and then extrapolated to the other 4 species living in different ecosystems (Miller et al. 1994).

Physiological and behavioral differences between Gunnison's (C. gunnisoni) and black-tailed prairie dogs (Rayor et al. 1987; Bakko et al. 1988) may potentially lead to differences in the effects these 2 species have on their ecosystems. Because Gunnison's prairie dogs hibernate and are inactive much of the year, there may be fewer differences in vegetation on and off their towns than on and off black-tailed prairie dog towns. For example, a year after the reintroduction of Gunnison's prairie dogs to the Sevilleta National Wildlife Refuge in New Mexico, no difference in plant cover or species richness was detected (Davidson et al. 1999). Furthermore, Gunnison's prairie dogs are generally found at higher elevations than black-tailed prairie dogs. Thus, the plant species in their ecosystem may respond differently to prairie dog activities than those in other grassland types. In an attempt to elucidate the effects of Gunnison's prairie dogs on the ecosystem, we examined cover and biomass of plant species and plant functional groups (graminoid, forb, shrub, and subshrub), plant species richness and diversity, canopy height, and nitrogen concentrations in the dominant plants on and off Gunnison's prairie dog towns. We hypothesized that cover and biomass of forbs and subshrubs and plant nitrogen concentrations would increase and that cover and biomass of grasses and canopy height would decrease on prairie dog towns. We also hypothesized that plant species diversity would not be significantly different on and off prairie dog towns.

\section{METHODS}

\section{Study Area}

We sampled 3 sites located $45 \mathrm{~km}$ southeast of Gunnison, Colorado (lat $38^{\prime} 13^{\prime \prime} \mathrm{N}$, long $\left.106^{\prime} 45^{\prime \prime} \mathrm{W}\right), 2$ sites $10 \mathrm{~km}$ southwest of Monte Vista, Colorado (lat $37^{\prime} 32^{\prime \prime} \mathrm{N}$, long $\left.106^{\prime} 11^{\prime \prime} \mathrm{W}\right)$, and 1 site $40 \mathrm{~km}$ northwest of Monte Vista, just west of La Garita, Colorado (lat $37^{\prime} 50^{\prime \prime} \mathrm{N}$, long $106^{\prime} 15^{\prime \prime} \mathrm{W}$ ) during the summer of 2002. The prairie dog towns varied from 12 to 38 ha. Each site consisted of a Gunnison's prairie dog town and a nearby off-town plot of similar slope, vegetation type, and soils.

Topography at the 3 Gunnison sites ranged from rolling hills to mountains, and the sites were well-drained, gravelly, sandy loams (Hunter and Spears 1975) with high evaporation and rapid water percolation (Johnston et al. 2001). Vegetation at the sites was dominated by Rocky Mountain fescue (Festuca saximontana) (Johnston et al. 2001). Nomenclature follows USDA plants database (USDA 2003). Graminoid cover in these areas is usually $50 \%-80 \%$, and our sites fell on the lower end of this range (Grant 2003). The Gunnison sites ranged from 2730 to $2840 \mathrm{~m}$ in elevation and had an annual average precipitation of $300 \mathrm{~mm}$ (Colorado Climate Center 2003).

Topography around Monte Vista was generally flat with only small hills. Plant species composition at the 3 Monte Vista sites was similar to that at the Gunnison sites, but vegetation was dominated by blue grama (Bouteloua gracilis Lag. ex Griffiths). They were also lower in elevation (2 360-2 $400 \mathrm{~m}$ ) and drier (200 $\mathrm{mm}$ average annual precipitation) than the Gunnison sites (Colorado Climate Center 2003).

All sites are currently, and historically have been, grazed by livestock. Gunnison's prairie dog towns and off-town sites were located within grazing allotments with similar grazing histories. Grazing allotments near Gunnison were from 800 to 2000 ha and were grazed by as many as 414 cattle per allotment from May to October in the 1970s (Bureau of Land Management [BLM] records, Gunnison unpublished data). Current rates are about 45 cattle per allotment between June and September, with sheep (1 090 sheep) grazing between 1 June and 15 June (BLM records, Gunnison unpublished data). At the Monte Vista sites, allotments were grazed during the fall and winter by cattle, about 1150 animal unit months (AUM), within an area of about 5870 ha from 1941 to 1997 . Current rates are 350 AUM of cattle during spring, summer, and fall (BLM records, Monte Vista unpublished data).

\section{Plant Species Composition and Cover}

We surveyed vegetation on and off prairie dog towns using Modified-Whittaker (M-W) vegetation plots (Stohlgren et al. 1995). Each M-W plot is $20 \times 50 \mathrm{~m}\left(1000 \mathrm{~m}^{2}\right)$, with $15 \times 20-\mathrm{m}$ subplot, $25 \times 2$-m subplots, and $100.5 \times 2$-m subplots located within the largest plot. Two M-W plots were sampled on each prairie dog town and on each off-town site. The locations of these plots were chosen randomly from 5 preselected locations. Preselected locations were in areas with active mounds on prairie dog towns and in areas off towns with similar characteristics. Following procedures of Stohlgren et al. (1995), we visually estimated cover $(\%)$ of all plant species within the 10 $1-\mathrm{m}^{2}$ subplots of each $\mathrm{M}-\mathrm{W}$ plot and recorded all plant species present in the 3 larger subplots and the entire M-W plot. All $\mathrm{M}-\mathrm{W}$ plots were sampled near the end of the field season (28 June-12 July 2002).

Shannon-Weiner diversity $\left(\mathrm{H}^{\prime}\right)$ was calculated from each $\mathrm{M}-\mathrm{W}$ plot as

$$
\mathrm{H}^{\prime}=\sum_{i=1}^{i=s}\left(p_{i}\right)\left(\ln p_{i}\right)
$$

where $p_{i}$ is the proportion of species $(i)$ in the sample based on percent cover of plants within each M-W plot and $s$ is the number of species sampled. Species richness on and off prairie dog towns was compared with a $t$ test and species area curves (Estimate-S 2001). 


\section{Plant Biomass and Canopy Height}

Standing biomass was measured on and off prairie dog towns in late July 2002. Within each M-W plot, vegetation from 2 randomly located $0.25-\mathrm{m}^{2}$ plots was harvested, totaling 4 clipped plots per prairie dog town and 4 in each off-town area. Plant functional groups were separated into standing dead and live components, dried at $50^{\circ} \mathrm{C}$ for approximately 48 hours, and weighed.

We measured canopy height within each of the $1-\mathrm{m}^{2}$ subplots of each M-W plot. A light piece of Styrofoam $(50 \times$ $25 \mathrm{~cm}$ ) was placed on top of the vegetation in the center of each $1-\mathrm{m}^{2}$ plot. Vegetation canopy height was measured through a small hole in the center of the Styrofoam piece.

\section{Plant Nitrogen Concentration}

Live plant samples were collected randomly from the 3 sites near Gunnison for nitrogen analysis. Samples consisted of plant shoots, including leaves or blades, and no reproductive parts were collected. One sample of each of the dominant plant species (as determined by cover), Rocky Mountain fescue, slim stem muhly (Mublenbergia filiculmis), rubber rabbitbrush (Ericameria nauseosa), and prairie sagewort (Artemisia frigida) was collected from each of the M-W plots. A total of 6 samples per species on and 6 samples off prairie dog towns were collected per sample date (31 May, 21 June, and 17 July 2002). Samples were dried for 48 hours at $50^{\circ} \mathrm{C}$, ground with a Wiley mill, and analyzed with a LECO-CHN analyzer.

\section{Statistical Analysis}

We used multiple analysis of variance (MANOVA; SAS 2002) to test for differences $(P<0.05)$ in cover of plant species as well as for cover of bare ground, rock, and lichen on and off prairie dog towns (Scheiner 2001). The model for this test was all plant species, ground, rock, and lichen as the dependent variables and location (Gunnison or Monte Vista), town (either on or off the prairie $\operatorname{dog}$ town), and a town-by-location interaction as independent variables $(\mathrm{y}=$ location + town + location $\times$ town). We also used MANOVA to test for differences in cover of plant functional groups (forbs, graminoids, shrubs, litter, and bare ground plus rock) and biomass of plant functional groups (graminoids, forbs, and subshrubs) on and off prairie dog towns. Plant functional groups served as dependent variables (Scheiner 2001). Independent variables were constant among models. Analysis of variance (ANOVA) was used to test for differences $(P<0.05)$ in canopy height and species diversity $\left(\mathrm{H}^{\prime}\right)$ (SAS 2002). Dependent variables in these models were the same as for cover and biomass models (SAS 2002). Degrees of freedom were determined using the Satterthwaite method when appropriate (Neter et al. 1996).

We also used MANOVA (SAS 2002) to test for differences in shoot nitrogen concentration (in the 4 dominant plant species) on and off prairie dog towns (Scheiner 2001). This model included the 4 plant species as dependent variables and the independent variables included date sampled, site ( 1 of 3 sites near Gunnison), town (on or off prairie dog towns), and a dateby-town interaction. Because of significant results for the MANOVA test, ANOVA tests for each focal plant were performed. MANOVA and ANOVA were done for Gunnison and Monte Vista separately and combined. Because of similar-
Table 1. Observed differences in response variables on and off of prairie dog towns (on-town averages - off-town averages), along with calculated minimum detectable effects (based on observed standard error) and 95\% confidence limits. Response variables include percent cover of functional groups (Cover) including bare ground plus rock (Ground), Graminoid, Forb, Shrub; biomass in $\mathrm{g} / \mathrm{m}^{2}$ of plant functional groups (Biomass) including live forbs, standing dead forbs, live graminoids, standing dead graminoids, live subshrubs, and standing dead subshrubs; and percent nitrogen concentration (Nitrogen) of the 4 plants with the greatest cover. FESA indicates Festuca saximontana; MUFI, Muhlenbergia filiculmis; ARFR, Artemisia frigida; and ERNA, Ericameria nauseosa; canopy height (Canopy) in centimeters; plant species diversity (Diversity) as indicated by Shannon-Weiner diversity indices $\left(\mathrm{H}^{\prime}\right)$.

\begin{tabular}{lccc}
\hline Response variable & $\begin{array}{c}\text { Observed } \\
\text { difference }\end{array}$ & $\begin{array}{c}\text { Detectable } \\
\text { difference }\end{array}$ & $\begin{array}{c}\text { Confidence } \\
\text { limits }\end{array}$ \\
\hline Cover (\%) & & & \\
Ground & 2.87 & 12.08 & $7.24,34.72$ \\
Graminoid & -2.92 & 24.70 & $14.8,70.98$ \\
Forb & 0.36 & 29.59 & $17.73,85.03$ \\
Shrub & -1.05 & 10.28 & $6.16,29.54$ \\
Biomass (g/m $\left.{ }^{2}\right)$ & & & \\
Live forb & & 0.78 & $0.47,2.26$ \\
Dead forb & -0.16 & 5.52 & $3.31,15.87$ \\
Live graminoid & -0.49 & 2.19 & $1.31,6.31$ \\
Dead graminoid & -0.96 & 5.09 & $3.05,14.63$ \\
Live subshrub & 0.72 & 8.30 & $4.97,23.86$ \\
Dead subshrub & 0.46 & 2.11 & $1.26,6.07$ \\
Nitrogen (\%) & & & \\
FESA & & & \\
MUFI & 0.003 & 0.68 & $0.41,1.97$ \\
ARFR & 0.10 & 0.60 & $0.36,1.73$ \\
ERNA & 0.21 & 0.80 & $0.48,2.31$ \\
Canopy (cm) & 0.22 & 1.25 & $0.75,3.60$ \\
Diversity (H') & -0.97 & 5.97 & $3.58,17.15$ \\
\hline & -0.07 & 0.77 & $0.46,2.22$ \\
\hline
\end{tabular}

ities in results from the 2 areas sampled, only combined data are presented.

\section{Minimal Detectable Effects}

Retrospective analyses for minimal detectable effects were performed using observed standard deviations from ANOVA analyses done on each independent variable (Table 1) (Steidl and Thomas 2001). These can be controversial and should be carefully considered (Rotenberry and Wiens 1985; Steidl and Thomas 2001).

\section{RESULTS}

\section{Plant Cover, Biomass, and Diversity}

Graminoids dominated the cover, with about 4 times greater cover than that of any other plant functional group (Fig. 1). Biomass of dead graminoids was greater than that of any other functional group but averaged only about $11 \mathrm{~g} / \mathrm{m}^{2}$, while live graminoids averaged only $2 \mathrm{~g} / \mathrm{m}^{2}$ (Fig. 2). There were no significant differences $(P>0.07)$ in cover of individual plant 


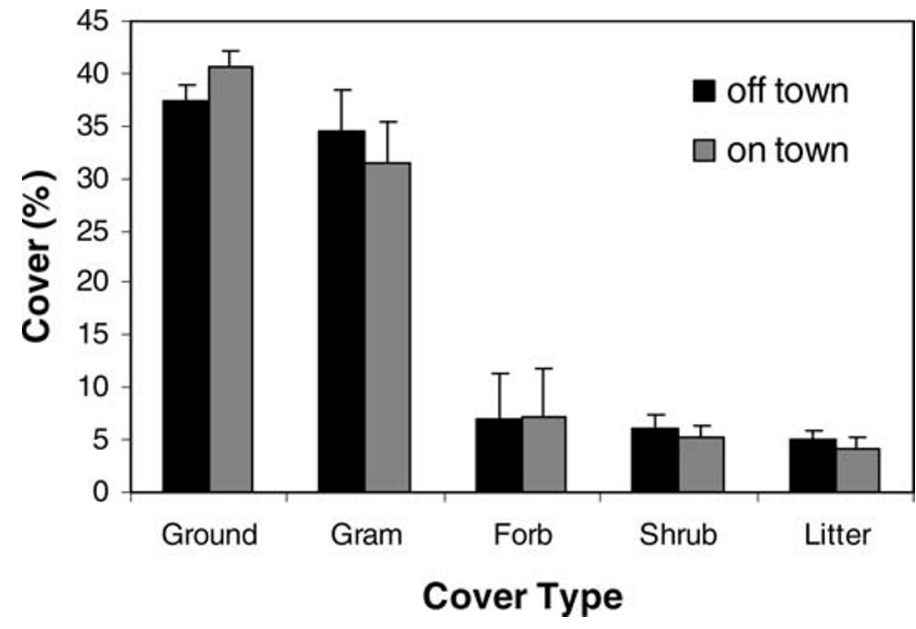

Figure 1. Cover ( $\% \pm 1 \mathrm{SE})$ of functional groups, including bare ground plus rock (Ground), graminoids (Gram), forbs (Forb), shrubs (Shrub), and litter (Litter) on and off Gunnison's prairie dog towns at all 6 sites combined. No significant differences $(P>0.1)$ were found using analysis of variance.

species (data not shown) or plant functional groups $(P>0.16)$ on and off prairie dog towns (Fig. 1). There were also no significant differences $(P>0.06)$ in biomass of any functional group on and off prairie dog towns (Fig. 2). No significant difference on and off prairie dog towns was found in plant species richness $(P=0.07)$. While species area curves show a leveling of plant species found at the number of plots sampled, drought may have suppressed this number (Fig. 3). Therefore, it cannot be assumed that all possible species were sampled. No significant differences in diversity indices were found on (average $\mathrm{H}^{\prime}=1.45$ ) and off (average $\mathrm{H}^{\prime}=1.50$ ) prairie dog towns. However, species area curves may suggest a trend of more species off prairie dog towns (Fig. 3). More research would be needed to confirm or refute this trend.

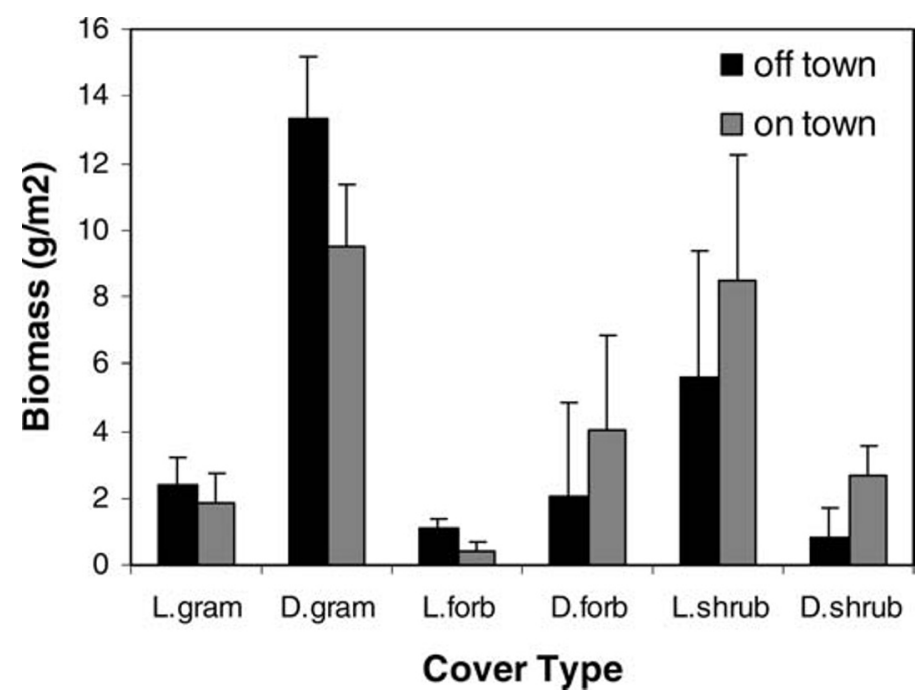

Figure 2. Biomass $\left(\mathrm{g} / \mathrm{m}^{2} \pm 1 \mathrm{SE}\right)$ of plant functional groups: live graminoids (L.gram), standing dead graminoids (D.gram), live forbs (L.forb), standing dead forbs (D.forb), live subshrubs (L.shrub), and standing dead subshrubs (D.shrub). No significant differences $(P>0.1)$ on and off prairie dog towns were found using analysis of variance.

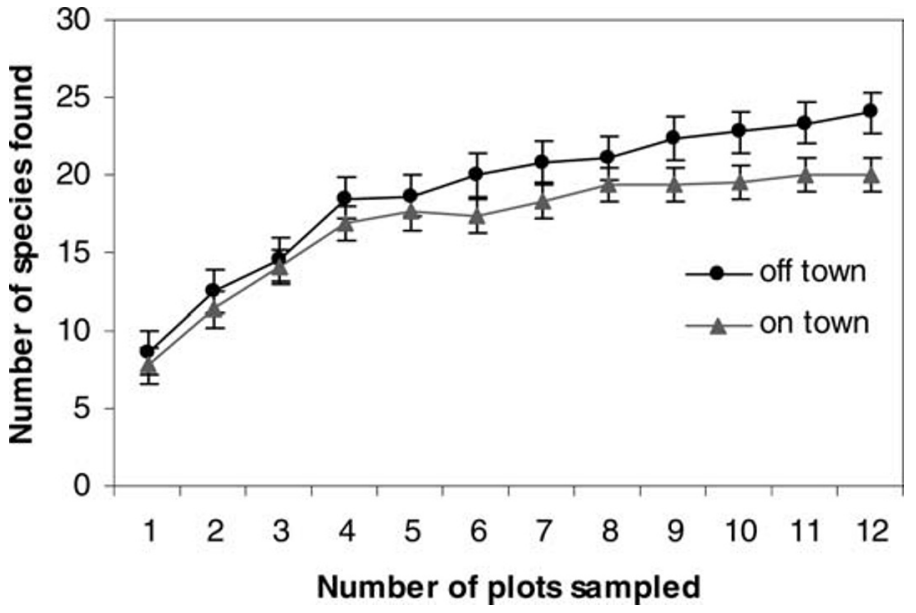

Figure 3. Species area curves $( \pm 1 \mathrm{SE})$ for plant species found on and off Gunnison's prairie dog towns in Modified-Whittaker plots ( $n=2 /$ site) at all 6 sites combined.

\section{Canopy Height and Plant Nitrogen Concentration}

Canopy height, which averaged $5 \mathrm{~cm}$ at the sites near Gunnison and $7 \mathrm{~cm}$ at the sites near Monte Vista, was not significantly different $(P=0.33)$ on and off prairie dog towns at any of the sites.

Only 1 of the 4 dominant plant species showed a significant difference in nitrogen concentration on and off prairie dog towns. While least square means showed virtually no differences in nitrogen concentration on and off prairie dog towns in the grass species $(M$. filiculmis, $P=0.18, F$. saximontana, $P=$ 0.52 ), there were noticeable differences in the shrub and subshrub species sampled (E. nauseosa, $P=0.01$, A. frigida, $P=0.07$ ) (Fig. 4). Nitrogen concentration fluctuated in all plant species over the 3 sampling periods $(P<0.01)$. However, there was not a date-by-town interaction $(P>0.15)$ for any of the species, indicating that seasonal fluctuations are independent of prairie dog town location.

\section{Minimal Detectable Effects}

We found that our observed differences were undetectable for all categories tested (Table 1). However, this is acceptable, as observed differences were small and likely not of biological significance.

\section{DISCUSSION}

Drought in the study areas may have masked differences in vegetation on and off prairie dog towns. The Gunnison area was in its second consecutive year of drought, receiving $72 \%$ and $53 \%$ of average annual precipitation in 2000-2001 and 20012002, respectively (Colorado Climate Center 2003). The Monte Vista area received only $67 \%$ of yearly average precipitation in 2001-2002 but received above-average (155\%) yearly precipitation during 2000-2001 (Colorado Climate Center 2003). Many of our results may have been affected by the drought, as live vegetation was sparse. However, we included standing dead vegetation in our sampling and therefore have an indication of vegetation in predrought conditions. Prairie dog populations may have also been low because of drought. On average, $52 \%$ of 
prairie dog mounds were active at the Gunnison sites with average total density of 123 mounds/ha. Only 34\% of mounds were active at the Monte Vista sites, with an average density of 93 mounds/ha. Although mound density is not necessarily correlated with prairie dog populations (Severson and Plumb 1998), the possibility of low prairie dog populations should be considered.

\section{Plant Cover and Biomass}

Although a study in Arizona found a negative correlation between plant cover and Gunnison's prairie dog mound density (Slobodchikoff et al. 1988), we found no significant differences for cover of plant functional groups on and off Gunnison's prairie dog towns. Also, contrary to what has been reported for black-tailed prairie dogs (Coppock et al. 1983; Archer et al. 1987; Winter et al. 2002) and what we hypothesized for Gunnison's prairie dogs, a decrease in grass cover with a corresponding increase in cover of forbs and subshrubs was not found. While there was no significant difference $(P=0.19)$, visual observations indicated an increase in fringed sagewort on Gunnison's prairie dog towns. However, our research suggests that vegetation changes on Gunnison's prairie dog towns may be subtler than those on black-tailed prairie dog towns, which often have dramatic shifts in vegetation, thereby creating conspicuous patches in the grassland landscape (Coppock et al. 1983; Archer et al. 1987; Winter et al. 2002).

Although bare ground cover often is greater on than off black-tailed prairie dog towns (Coppock et al. 1983; Archer et al. 1987), there were no such differences on and off Gunnison's prairie dog towns. This also supports the idea that the magnitude of vegetation and landscape changes on Gunnison's prairie dog towns is less than on black-tailed prairie dog towns. This may be in part due to the caespitose growth habits of the dominant grasses Rocky Mountain fescue, slim stem muhly, and blue grama. The dense clumps of these grasses can have considerable ground cover even when heavily grazed. Guenther and Detling (2003) found few differences in bare ground on black-tailed prairie dog towns in the semiarid shortgrass steppe dominated by blue grama.

Also in contrast to our hypotheses, there were few significant differences in plant biomass on and off Gunnison prairie dog towns. While older black-tailed prairie dog towns typically have higher biomass of forbs and lower biomass of grasses (Coppock et al. 1983; Winter et al. 2002), we did not find these patterns on Gunnison's prairie dog towns. The low precipitation undoubtedly reduced the biomass of vegetation; however, Gunnison's prairie dogs may not affect plant biomass as dramatically as do black-tailed prairie dogs. Some reasons for this could be their less gregarious behavior, hibernation (and hence reduced feeding duration), and diet. Black-tailed prairie dogs eat primarily grasses (Bohnam and Lerwick 1976; Uresk 1984), although they will also consume forbs and subshrubs (Uresk 1984). The specific diet of Gunnison's prairie dogs may vary over a growing season (Shalaway and Slobodchikoff 1988) and likely overlaps with that of black-tailed prairie dogs. Gunnison's prairie dogs may also supplement their diet with seeds (Shalaway and Slobodchikoff 1988).

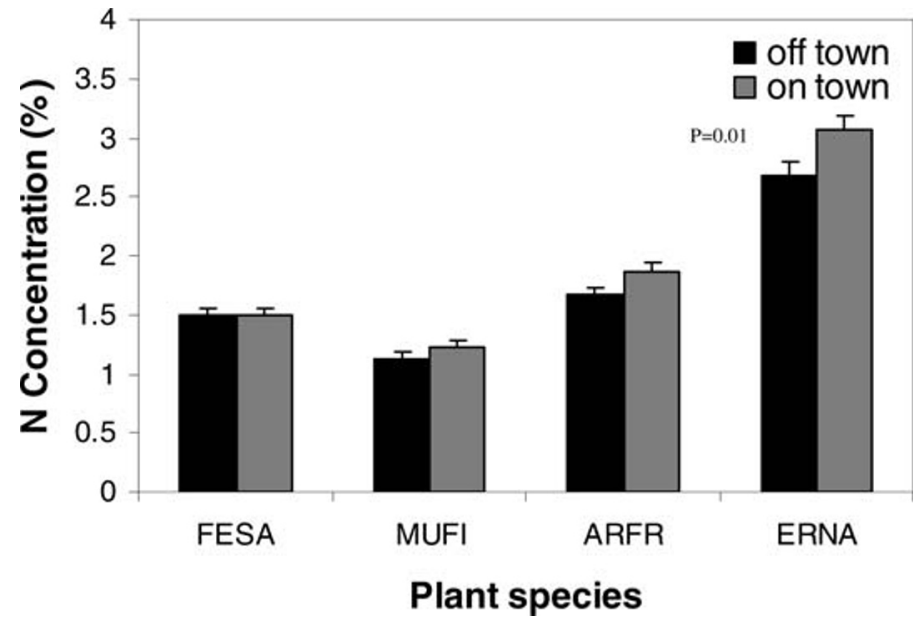

Figure 4. Plant nitrogen concentration $(\% \pm 1 \mathrm{SE})$ for the 4 plant species with greatest cover at 3 sites near Gunnison, Colorado. Values are an average of nitrogen concentrations from the 3 sample dates. Each bar represents the mean of 18 samples. FESA indicates Festuca saximontana; MUFI, Muhlenbergia filiculmis; ARFR, Artemisia frigida; and ERNA, Ericameria nauseosa.

\section{Canopy Height}

Vegetation canopy height is often reduced on black-tailed prairie dog towns (Archer et al. 1987; Winter et al. 2002), partly as a result of consumption and partly as a result of active clipping of the vegetation by prairie dogs allowing predator scanning (Hoogland 1995). Average canopy height was lower on $(10 \mathrm{~cm})$ than off $(20 \mathrm{~cm})$ black-tailed prairie dog towns in the mixed grass prairie (Archer et al. 1987) and in the shortgrass steppe, where canopy height was about $6 \mathrm{~cm}$ on prairie dog towns and $12 \mathrm{~cm}$ off towns (Guenther and Detling 2003). However, we found no significant difference in canopy height on and off of Gunnison's prairie dog towns. The short stature of the vegetation in the areas sampled may preclude Gunnison's prairie dogs from further shortening the vegetation, as predator scanning may not be inhibited by already low vegetation.

\section{Plant Species Diversity}

Plant species diversity is similar on and off of black-tailed prairie dog towns in the shortgrass steppe (Winter et al. 2002). However, studies in the mixed grass prairie have shown that species diversity is higher on young to middle-aged towns and lower on older towns (Coppock et al. 1983; Archer et al. 1987). This is consistent with the ecological paradigm that moderate disturbances create the greatest biological diversity (Huston 1979).

Because of the drought in both study areas, it is likely that many forbs that would normally be found did not grow during this field season. Shannon-Weiner indices (HN) were low (0.92.0) for all areas sampled. However, no differences were found in plant species diversity or richness on and off of Gunnison's prairie dog towns, supporting our hypothesis that plant species diversity and richness are similar on and off of Gunnison's prairie dog towns. The absence of differences in the cover of dominant plant species provides further support for this hypothesis. It has been suggested that Gunnison's prairie dogs 
may have an effect on the heterogeneity of the landscape at larger scales (Bangert and Slobodchikoff 2000). While species area curves suggested a trend of higher plant richness off towns, because of low diversity indices more research would be needed to support or refute this trend.

\section{Plant Nitrogen Concentration}

Previous studies have found shoot nitrogen concentration of certain plants to be higher on black-tailed prairie dog towns than off-town sites (Coppock et al. 1983; Farrar 2002). This is important, as an increase in plant nitrogen concentration is loosely related to increases in forage quality and digestibility (Coppock et al. 1983; Milchunas et al. 1995). Higher nitrogen concentrations of plants on black-tailed prairie dog towns have been attributed to more prostrate growth forms, which have greater nitrogen-rich leaf blade area and lower nitrogenpoor stem area (Whicker and Detling 1988), increased nitrogen inputs from urine and fecal deposits, and soil mixing (Coppock et al. 1983; Farrar 2002). Nitrogen mineralization may also be higher on black-tailed prairie dog towns than off towns (Holland and Detling 1990), increasing available nitrogen to plants.

Our data showed a significant difference in nitrogen concentration on and off prairie dog towns only in rubber rabbitbrush. However, the drought may have influenced the results, as soil moisture may control nitrogen mineralization (Holland and Detling 1990). More research would be needed to conclusively show whether, like black-tailed prairie dogs, Gunnison's prairie dogs increase nitrogen concentrations in plants on towns.

\section{CONCLUSIONS}

Similarities in vegetation were more common than differences on and off Gunnison's prairie dog towns. Furthermore, differences found on and off Gunnison's prairie dog towns were less dramatic than those typically reported for black-tailed prairie dog towns. The contradiction of these results and those found in studies of black-tailed prairie dogs may stem from the differences in the ecosystems inhabited by the 2 species, hibernation and behavioral differences, or drought.

\section{MANAGEMENT IMPLICATIONS}

This research emphasizes that while generalizations in ecology can be important, researchers and managers should be careful that these generalizations do not obscure important ecological differences. While some patterns may hold over prairie dog species lines, each species may have different effects on the landscape, and the levels of disturbance created by these species may be especially different. Management plans should consider both the ecosystem and prairie dog species involved.

\section{ACKNOWLEDGMENTS}

We wish to thank the Monte Vista BLM office, Shawn Kelly, Joe Capodice, Sandy Hayes, Vinnie Rosignal, Art Hayes, Barry Tollefson, and Aaron
Hoffman for all of their help with fieldwork, lab work, plant identification, and logistical support.

\section{LITERATURE CITED}

Archer, S., M. Garrett, and J. K. Detling. 1987. Rates of vegetation change associated with prairie dog (Cynomys ludovicianus) grazing in North American mixed-grass prairie. Vegetatio 72:159-166.

Bakko, E. B., W. P. Porter, and B. A. Wunder. 1988. Body temperature patterns in black-tailed prairie dogs in the field. Canadian Journal of Zoology 66: 1783-1789.

Bangert, R. K., and C. N. Slobodchikoff. 2000. The Gunnison's prairie dog structures a high desert grassland landscape as a keystone engineer. Journal of Arid Environments 46:357-369.

Bohnam, C. D., AND A. LerWICK. 1976. Vegetation change induced by prairie dogs on shortgrass range. Journal of Range Management 29:221-225.

Colorado Climate Center. 2003. Long term climate-Colorado resources. Available at: http://climate.atmos.colostate.edu/coloradoclimate.shtml. Accessed 3 February 2003.

Coppock, D. L., J. K. Detling, J. E. Ellis, and M. I. Dyer. 1983. Plantherbivore interactions in a North American mixed grass prairie I. Effects of black-tailed prairie dogs on intraseasonal aboveground plant biomass and nutrient dynamics and plant species diversity. Oecologia $56: 1-9$.

Cully, J. F., And E. S. Williams. 2001. Interspecific comparisons of sylvatic plague in prairie dogs. Journal of Mammalogy 82:894-905.

Davidson, A. D., R. R. Parmenter, and J. R. Gosz. 1999. Responses of small mammals and vegetation to a reintroduction of Gunnison's prairie dogs. Journal of Mammalogy 80:1311-1324.

Estimate-S. 2001. Version 5.0.1. Available at: http://viceroy.eeb.uconn.edu/ EstimateS. Accessed 30 August 2001.

FARRAR, J. P. 2002. Effects of prairie dog mound-building and grazing activities on vegetation in the central grasslands [thesis]. Fort Collins, CO: Colorado State University. $41 \mathrm{p}$

Grant, M. N. 2003. Effects of Gunnison's prairie dogs (Cynomys gunnisoni) on vegetation structure and composition [thesis]. Fort Collins, CO: Colorado State University. $55 \mathrm{p}$.

Guenther, D., And J. K. Detling. 2003. Observations of cattle use of prairie dog towns. Journal of Range Management 56:410-417.

Holland, E. A., and J. K. Detling. 1990. Plant response to herbivory and belowground nitrogen cycling. Ecology 71:1040-1049.

Hoogland, J. L. 1995. The black-tailed prairie dog: Social life of a burrowing mammal. Chicago, IL: University of Chicago Press. $557 \mathrm{p}$.

Hunter, W. R., and C. F. Spears. 1975. Soil survey of Gunnison area Colorado; parts of Gunnison, Hinsdale, and Saguache Counties. Washington, DC: USDA Soil Conservation Service and Colorado Agricultural Experiment Station. Report A57. 38:G95. 86 p.

Huston, M. 1979. A general hypothesis of species diversity. American Naturalist 113:81-101.

Johnston, B. C., L. Huckabey, T. J. Hughes, and J. Pecor. 2001. Ecological types of the Upper Gunnison Basin: vegetation-soil-landform-geology-climatewater-land classes for natural resource management. Lakewood, CO: USDA Forest Service. Rocky Mountain Region. Technical Report R2-RR-2001-01. $858 \mathrm{p}$.

Kotliar, N. B., B. W. Baker, and A. D. Whicker. 1999. A critical review of assumptions about the prairie dog as a keystone species. Environmental Management 24:177-192.

MerRIAm, C. H. 1902. The prairie dog of the Great Plains. Washington, DC: US Department of Agriculture. US Department of Agriculture Yearbook (1901). p 257-270.

Milchunas, D. G., A. S. Varnamkhasti, and W. K. Lauenroth. 1995. Forage quality in relation to long-term grazing history, current-year defoliation, and water resource. Oecologia 101:366-374.

Miller B., G. Ceballos, and R. Reading. 1994. The prairie dog and biotic diversity. Conservation Biology 8:677-681. 
Neter, J., M. H. Kutner, C. J. Nachtsheim, and W. Wasserman. 1996. Applied linear statistical models. 4th ed. Boston, MA: McGraw-Hill. $1408 \mathrm{p}$.

RayoR, L. S., A. K. Brody, and C. Gllbert. 1987. Hibernation in the Gunnison's prairie dog. Journal of Mammalogy 68:147-150.

RotenBerRy, J. T., AND J. A. Wiens. 1985. Statistical power analysis and communitywide patterns. American Naturalist 125:164-168.

SAS. 2002. The SAS system for Windows. Version 8. Cary, NC: SAS Institute, Inc.

SCHEINER, S. M. 2001. MANOVA: Multiple response variables and multispecies interactions. In: S. M. Scheiner and J. Gurevitch [EDS.]. Design and analysis of ecological experiments. 2nd ed. New York, NY: Oxford University Press. p 99-115.

Severson, K. E., and G. E. Plumb. 1998. Comparison of methods to estimate population densities of black-tailed prairie dogs. Wildlife Society Bulletin 26:859-866.

Shalaway, S., and C. N. Slobodchikoff. 1988. Seasonal changes in the diet of Gunnison's prairie dog. Journal of Mammalogy 69:835-841.

Slobodchiкoff, C. N., A. Robinson, and C. SchaAck. 1988. Habitat use by Gunnison's prairie dogs. Presented at Symposium: Management of amphibians, reptiles, and small mammals in North America. R. C. Szaro, K. E. Severson, and D. R. Patton [EDS.]. Flagstaff, AZ: US Department of Agriculture. $p$ 403-408.

SteidL, R. J., and L. Thomas. 2001. Power analysis and experimental design. In: S. M. Scheiner and J. Gurevitch [EDS.]. Design and analysis of ecological experiments. 2nd ed. New York, NY: Oxford University Press. p 14-36.

Stohlgren, T. J., M. B. Falkner, and L. D. Schell. 1995. A Modified-Whittaker nested vegetation sampling method. Vegetatio 117:113-121.

URESK, D. W. 1984. Black-tailed prairie dog food habits and forage relationships in western South Dakota. Journal of Range Management 37:325-329.

[USDA] US Department of Agriculture. 2003. Plants Database Version 3.5. Available at: http://plants.usda.gov. Accessed 30 July 2003.

Whicker, A. D., And J. K. Detling. 1988. Ecological consequences of prairie dog disturbances. BioScience 38:778-784.

Winter, S. L., J. F. Cully, and J. S. Pontius. 2002. Vegetation of prairie dog colonies and non-colonized short-grass prairie. Journal of Range Management 55:502-508. 